\title{
Ultrastructural changes in the spinal cord of rats with experimental allergic encephalomyelitis under the influence of human umbilical cord-derived multipotent mesenchymal stromal cells cryopreserved according to different protocols
}

\author{
Tsymbaliuk V. ${ }^{1}$, Vaslovych V. ${ }^{1}$, Pichkur L. ${ }^{1}$, Liubich L. ${ }^{1}$, Malysheva T. ${ }^{1}$, Verbovska S. ${ }^{1}$, Egorova D. ${ }^{1}$, Lontkovskiy Yu. ${ }^{2}$ \\ ${ }^{1}$ The State Institution "Romodanov Neurosurgery Institute, National Academy of Medical Sciences of Ukraine", Kyiv, Ukraine \\ ${ }^{2}$ Medical center «MEDLON», Kamianets-Podilsky, Ukraine \\ Corresponding author’s e-mail: leoniddpichkur@gmail.com
}

\section{ABSTRACT}

The transplantation of multipotent mesenchymal stromal cells (MMSCS) is considered to be a possible therapy of multiple sclerosis. For the clinical application of human umbilical cord-derived MMSCS (UC-MMSCS) it is necessary to develop a method of their cryopreservation taking into account the type of cryoprotective media and to investigate the possibility of using these cells for therapeutic purposes in vivo.

The PURPOSE of the study was to investigate the effect of UC-MMSCs, cryopreserved in solutions of different composition, on the processes of demyelination and remyelination of the spinal cord of rats with experimental allergic encephalomyelitis (EAE) as a model of multiple sclerosis.

MATERIALS AND METHODS. The EAE was modeled by subcutaneous administration of homogenized spinal cord of adult rats with complete Freund's adjuvant. On the $18^{\text {th }}$ day rats with moderate relapsing-remitting form of EAE were suboccipitally injected 1・106 UC-MMSCs, cryopreserved in cryoprotective media containing dimethyl sulfoxide (DMSO), fetal bovine serum (FBS), ethylene glycol, trehalose and sucrose at different composition. On the $35^{\text {th }}$ and $60^{\text {th }}$ days, the studies of ultrastructural changes of the lumbar spinal cord (L3-L5) were performed, assessing the degree of demyelination of nerve fibers by the ratio of myelin sheath (MS) thickness to the diameter of the axis cylinder (AC) of axons.

RESULTS. In rats with moderate EAE from the $35^{\text {th }}$ to the $60^{\text {th }}$ day after the modelling of the disorder, destructive changes and signs of demyelination in the spinal cord increased; the MS/AC index corresponded to the average degree of axon demyelination. Suboccipitally administered cryopreserved UC-MMSCs to EAE rats, depending on the used cryopreservation solution, slowed or stopped the demyelination, decreased the MS/AC index to a low degree of axonal demyelination. Reducing the concentration of DMSO in the cryopreservation medium from $10 \%$ to $4 \%$ and adding $6 \%$ trehalose provided a better effectiveness of UC-MMSCs in decreasing the degree of demyelination in EAE. At the same time, the standard solution (10\% DMSO, $90 \%$ FBS) provided these effect, but to a lesser extent. The use of a multicomponent cryopreservation medium containing $15 \%$ ethylene glycol, $3 \%$ DMSO, $10 \%$ sucrose, $12 \%$ trehalose and $60 \%$ FBS did not achieve the goal of maintaining the effects of UC-MMSCs to reduce the degree of demyelination in EAE.

CONCLUSIONS. To maintain the therapeutic properties of UC-MMSCs, it is advisable to add a reduced concentration of DMSO (4 \%) and $6 \%$ trehalose to the cryopreservation medium, supplemented with $90 \%$ fetal bovine serum.

KEY WORDS: demyelination; remyelination, multipotent mesenchymal stromal cells; cell cryopreservation 
Multiple sclerosis is a chronic inflammatory degenerative disease of the central neural system (CNS), the pathogenesis of which is based on destructive autoimmune reactions, demyelination of axons in the foci of inflammation of the white matter of the brain, the predominance of degenerative processes over regeneration in conditions of myelin-forming cell deficiency [1]. There are still no effective treatments for this disease.

The studies of the effects of various therapeutic factors on the pathogenesis of multiple sclerosis are carried out on its model of experimental allergic encephalomyelitis (EAE) [2] due to the similarity of pathogenetic mechanisms.

A great hope in the treatment of this pathology is placed on the use of multipotent mesenchymal stromal cells (MMSCs). Warton's jelly of umbilical cord is considered to be the optimal source of their isolation because, unlike MMSCs of other origin, they have phenotypic and functional similarity in therapeutic potential with embryonic stem cells [3]. Administered into the cerebrospinal fluid MMSCs are able to survive and migrate to sites of CNS injury [4]. In EAE, MMSCs suppress the autoreactive T-cell response [5, 6], stimulate oligodendrogenesis, and inhibit demyelination and destruction of axons in the CNS [7]. Previous experimental studies have shown the positive effect of native MMSCs on the clinical course [8], behavioral responses [9], immune status [10-12] and morphological changes in the CNS of rats with EAE [13]. MMSCs transplantation is considered to be a possible direction of pathogenetic therapy of multiple sclerosis.

For clinical application of human umbilical cord-derived MMSCs (UCMMSCs) it is necessary to develop a method of their cryopreservation taking into account the type of cryoprotectants and investigate the possibility of using these cells for therapeutic purposes in vivo [14]. To date, dimethyl sulfoxide (DMSO) is mainly used as a cryoprotectant [15]. However, at certain concentrations it is toxic to cell membranes [16] and can cause adverse effects during infusions [17]. This is the basis for finding safe cryopreservatives that can protect cells from exposure to low temperatures. Such properties have multicomponent cryoprotectants with a significantly reduced concentration of DMSO due to the use of disaccharides [18].

Previous in vitro studies have shown the possibility of using different modes of cryopreservation of UC-MMSCs while preserving their phenotypic characteristics and proliferative activity [19]. The next task is to evaluate the possibility of in vivo application of UC-MMSCs, cryopreserved under different protocols.

The PURPOSE of the study was to investigate the effects of UCMMSCs, cryopreserved in cryopreservation media of different composition, on the processes of demyelination and remyelination in the spinal cord of rats with EAE.

\section{MATERIALS AND METHODS}

The studies were performed on outbred sexually mature female rats $(\mathrm{n}=33,3$ months old, weight $240 \pm 20 \mathrm{~g}$ ) breeding of the vivarium of the State Institution "Romodanov Neurosurgery Institute, National Academy of Medical Sciences of Ukraine" in accordance with the principles of the European Convention for the Protection of Vertebrate Animals Used for Experimental and Scientific Purposes (Strasbourg, 1986) and the Law of Ukraine №3447-IV "On the Protection of Animals against Cruelty" of 21.20.2006.

EAE was modeled by a single subcutaneous injection into the pads of the hind limbs of $0.2 \mathrm{~mL}$ of suspension of adult rats' spinal cord homogenized in saline (50 mg per $100 \mathrm{~g}$ of body weight), supplemented 1:1 with complete Freund's adjuvant (Sigma, USA), containing $2 \mathrm{mg} / \mathrm{mL}$ Mycobacterium tuberculosis, according to standardized methods [20]. This is a model of moderate relapsing-remitting EAE, which allows to study in detail the effects of various factors on the demyelinating process [2]. Anesthesia was performed by the injection of a mixture of xylazine $15 \mathrm{mg} / \mathrm{kg}$ ("Sedazin", Biovet, Poland) and ketamine $70 \mathrm{mg} / \mathrm{kg}$ ("Calypsol", Gedeon Richter, Hungary) intraperitoneally.
Table. 1. The composition of cryoprotectant solutions and characteristics of cryopreserved UC-MMSCs after thawing.

\begin{tabular}{|c|c|c|c|}
\hline NAME & CRYOPRESERVATION MEDIA & $\begin{array}{l}\text { VIABLE } \\
\text { CELLS, \% }\end{array}$ & $\begin{array}{l}\text { CD73+90+105+ } \\
\text { CELLS, \% }\end{array}$ \\
\hline CRYO-1 & $\begin{array}{l}15 \% \text { ethylene glycol, } \\
3 \% \text { DMSO, } 10 \% \text { sucrose, } \\
12 \% \text { trehalose, } 60 \% \text { FBS }\end{array}$ & $85.4 \pm 0.1$ & $99.6 \pm 0.4$ \\
\hline CRYO-2 & $\begin{array}{l}4 \% \text { DMSO, } 6 \% \text { trehalose, } \\
90 \% \text { FBS }\end{array}$ & $94.3 \pm 0.2$ & $99.9 \pm 0.1 \%$ \\
\hline CRYO-3 & $10 \%$ DMSO, $90 \%$ FBS & $95.9 \pm 0.1$ & $98.2 \pm 0.6 \%$ \\
\hline
\end{tabular}

Table. 2. Characteristics of experimental groups of animals.

\begin{tabular}{|c|c|c|c|c|}
\hline \multirow{3}{*}{ GROUP } & \multicolumn{4}{|c|}{ EXPERIMENT STAGE, NUMBER OF ANIMALS } \\
\hline & $\begin{array}{c}\text { EAE } \\
\text { MODEL }\end{array}$ & $\begin{array}{l}\text { UC-MMSCs } \\
\text { INJECTION }\end{array}$ & ELECTRON & ROSCOPY \\
\hline & day 0 & day $18^{\text {th }}$ & day $35^{\text {th }}$ & day $60^{\text {th }}$ \\
\hline EAE & $\mathrm{n}=7$ & - & $\mathrm{n}=4$ & $n=3$ \\
\hline $\begin{array}{l}\text { EAE + UC-MMSCs } \\
\text { cryo-1 }\end{array}$ & $\mathrm{n}=8$ & $n=8$ & $\mathrm{n}=4$ & $\mathrm{n}=4$ \\
\hline $\begin{array}{l}\text { EAE + UC-MMSCs } \\
\text { cryo-2 }\end{array}$ & $n=6$ & $\mathrm{n}=6$ & $n=3$ & $\mathrm{n}=3$ \\
\hline $\begin{array}{l}\text { EAE + UC-MMSCs } \\
\text { cryo-3 }\end{array}$ & $\mathrm{n}=8$ & $n=8$ & $n=4$ & $\mathrm{n}=4$ \\
\hline $\begin{array}{l}\text { Control (intact } \\
\text { animals) }\end{array}$ & - & - & & \\
\hline
\end{tabular}

On the $18^{\text {th }}$ day of the experiment, rats in the position of maximum bend of the neck were suboccipitally in the cisterna magna injected UCMMSCs $\left(1 \cdot 10^{6}\right.$ cells in $0.1 \mathrm{~mL}$ of saline per animal), cryopreserved in cryoprotective media with different composition of DMSO (Helicon, Russia), fetal bovine serum (FBS, BioWest, France) and other components: ethylene glycol (LaboChem, Germany), sucrose (BioFroxx, Germany), trehalose (BioFroxx, Germany) (table 1). According to the experimental conditions, experimental groups of animals were formed (table 2).

UC-MMSCs were obtained in accordance with the principles of bioethics from the umbilical cord during normal childbirth from a healthy mother by the informed consent. Cultivation, cryopreservation, thawing and washing were performed according to the previously described protocol [19]. The number and viability of the obtained cells was determined by counting in a Goryaev's chamber after staining with $0.2 \%$ trypan blue solution (AppliChem, Germany). The accordance of UC-MMSCs to the multipotent mesenchymal stromal cells was confirmed by the ability to differentiate in the osteogenic, chondrogenic and adipogenic directions and persisted after freezing and thawing [19]. The variants of the composition of cryopreservation media did not affect the expression of specific surface markers $\mathrm{CD}^{+}{ }^{+}, \mathrm{CD}^{+} 0^{+}, \mathrm{CD} 105^{+}$, determined by flow cytometry [19].

To study the processes of demyelination and remyelination of nerve fibers using electron microscopy, we performed the studies of ultrastructural changes of the lumbar segments (L3-L5) of the spinal cord of experimental rats in the medial part of the ventral horn (including areas of IX laminae, and, partly, VIII and VII laminae according to the Rexed laminae system) on the $35^{\text {th }}$ and $60^{\text {th }}$ day of the experiment. The animals were euthanized by the overdose of ether, samples of tissue of the lumbar spinal cord for 1-2 $\mathrm{mm}^{3}$ were excised immediately, fixed in a solution of $4 \%$ paraformaldehyde (Aldrich, Germany), $2.5 \%$ glutaraldehyde (Raaral, Hungary) on $0.1 \mathrm{M}$ cacodylate buffer pH 7.4 (Agar scientific, Germany) followed by fixation in $1 \%$ osmium tetroxide (Agar scientific, Germany) 
[21], dehydrated in increasing concentrations of ethanol and propylene oxide and mounted into a Epon-Araldite (Fluka, Switzerland) by standard methods of electron microscopy [22]. Ultrathin sections for $70 \mathrm{~nm}$ were performed on an ultratome LKB-8800 (Sweden). To increase the contrast, they were stained by the method of Reynolds (1963) [23] and examined in an electron microscope TEM 100-1 (SELMI, Ukraine) at an accelerating voltage of $75 \mathrm{kV}$. For targeted ultratoming and a deeper assessment, semi-thin sections for 100-150 nm were prepared from epoxy blocks, stained with methylene blue-pyronine and examined under an optical microscope Axiophot (Zeiss, Germany).

The evaluation of the degree of demyelination in nerve fibers of the lumbar spinal cord was performed using the developed morphometric index - the ratio of the thickness of the myelin sheath (MS) to the diameter of the axis cylinder (AC) [24] by morphometric analysis of transverse semi-thin sections on a image analyzer SAI-01AVN (SELMI, Ukraine) using software "Kappa opto-electronics GmbH" (Germany) at the same magnification (lens $\times 40$, adapter $\times 2$, eyepiece $\times 10$ ). The correlation coefficient of MS/AC was determined from the analysis of 30 randomly myelinated axons per 1 case. Normally, the MS/AC is $0.15-0.35$. At the value of the MS/AC in the range of $0.36-0.43$ the degree of demyelination is estimated as low, 0.44-0.54 as medium, more than 0.55 as high [24]. Remyelination was evaluated as normalization of the state of the myelin sheath of axons (in particular, as a decrease in the degree of demyelination of MS/AC) and normalization of the intraaxonal organelles.

Methods of variation statistics were used for statistical analysis of the obtained data. The normality of the data distribution was checked by the Shapiro-Wilk test. For multiple intergroup comparisons, a nonparametric Kruskal-Wallis one-way analysis of variance was used in STATISTICA 7 software (StatSoft Inc., USA), which is equivalent to multiple comparisons using the Mann-Whitney U-test [25, 26]. Pairwise comparisons were followed by adjustments by Holm-Bonferroni correction for multiple comparisons using MS Excel 2013 (Microsoft. USA). The values were represented as $\mathrm{M}(25 \% ; 75 \%)(\mathrm{n})$, where $\mathrm{M}$ is the median with interquartile range.

\section{RESULTS AND DISCUSSION}

Group 1 (EAE). On the $35^{\text {th }}$ day after the induction of EAE in the lumbar segments (L3-L5) of the spinal cord in the medial part of the ventral horn of rats, along with a few reactive altered "light" neurons, destructive altered "dark" osmophilic motor multipolar neurons of gray matter (neuron body diameter 100-150 $\mu \mathrm{m}$ [28]) were revealed. Their nuclei were characterized by high electron density with significant local expansions of the perinuclear space. Expanded cysterns of the endoplasmic reticulum (EPR) formed elongated cavities in the osmophilic cytoplasm of the cell (Fig. 1 A). The number of free ribosomes and polysomes in the cytoplasm was low. At the same time, the content of lysosomes in the cytoplasm of a significant number of neurons was increased. Individual hyperchromic preapoptically altered neurons with a pyknotic nucleus and significant expansion of the tubular EPR were detected. Axo-dendritic and axo-somatic synapses with the signs of destruction of the "light" type were observed: swelling of the cytoplasm of the presynaptic terminal, appearance of vacuoles, changes in mitochondria with the signs of swelling, clarification of the matrix and partial destruction of the cristae, disorganization of synaptic vesicles.

On the $60^{\text {th }}$ day of the experiment, the number of altered neurons slightly increased. The detected disorders of the ultrastructure of neurons resembled ischemic changes, which terminal stages are irreversible [29]. We also observed a large number of swollen synaptic terminals, with reduced electron density and a decrease in the number of synaptic vesicles and single synapses with reduced synaptic clefts (Fig. 1 B). Among the mitochondria of synaptic terminals there were sometimes sharply osmophilic types (Fig. 1 C), which may be a sign of ferroptosis [30].

According to the morphometric study, on the $35^{\text {th }}$ day after the induction of EAE, diffuse demyelination of axis cylinders was observed. The damage to the myelin sheath was characterized by the disorganization of the lamellae with diffuse interlamellar edema. Due to the loss of a part of the cytoskeletal microtubules and neurofilaments, the axoplasm acquired partial clearance. The destruction of intraaxonal mitochondria was observed. The MS/AC index, which characterizes the morphofunctional state of the myelin sheaths of nerve fibers, exceeded the control values by 1.3 times $(p=0.003$, table 3$)$. On the $60^{\text {th }}$ day of the experiment, these changes intensified; there was no decrease in the degree of demyelination. The defibering of myelin sheaths remained significant. The disorganization of axonal cytoskeleton, destructive changes of mitochondria and moderate periaxonal edema remained (Fig. 1 D). The MS/AC index increased relatively to the control 1.4 times $(p<0.0001$, table 3$)$, acquiring a value corresponding to the average degree of demyelination of axons [24], the morphological equivalent of which is defibering and disruption of the la-
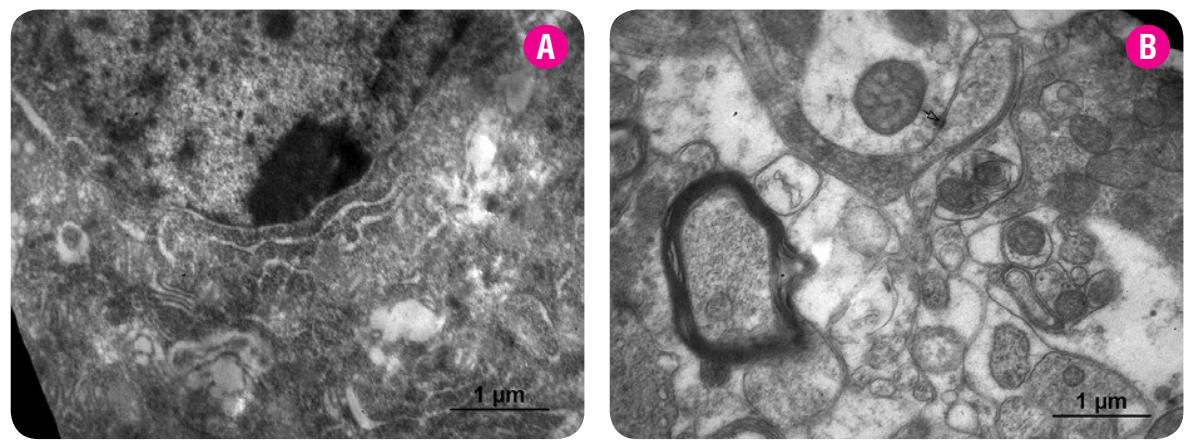

Fig. 1. Electronic microphotographs of rat spinal cord in group 1 (EAE): A) pre-apoptotic altered osmophilic neuron, day $35^{\text {th }}$

B) vacuolized postsynaptic terminals with a shortened contact zone (arrow), day $60^{\text {th }}$; C) osmophilic mitochondria in the synaptic terminal (arrow), day $35^{\text {th }}$

D) defibering of myelin sheaths (dark arrows), vacuolization of mitochondria (hollow arrows) in the axoplasm of a myelinated axon; day $60^{\text {th }}$
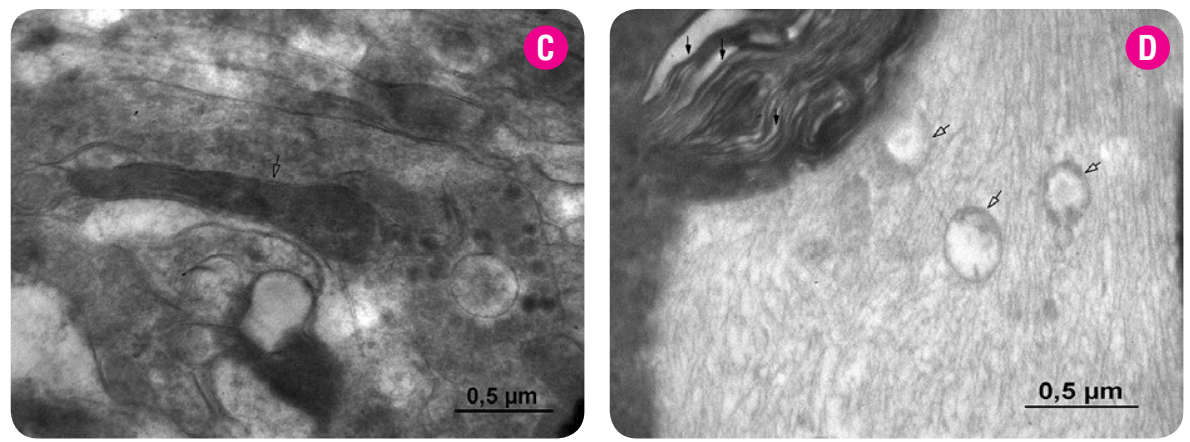

(D) 
Table. 3. Morphofunctional state of myelin sheaths of white matter nerve fibers of the lumbar segments of spinal cord of rats with EAE under the influence of suboccipital injection of UC-MMSCs, cryopreserved according to different protocols.

\begin{tabular}{|c|c|c|c|c|c|}
\hline \multirow{2}{*}{ № } & \multirow{2}{*}{ GROUPS } & \multicolumn{4}{|c|}{$\begin{array}{l}\text { THE RATIO OF THE THICKNESS OF THE MYELIN SHEATH TO THE } \\
\text { DIAMETER OF THE AXIS CYLINDER (MS/AC) }\end{array}$} \\
\hline & & $\begin{array}{c}\text { DAY } 35^{\mathrm{TH}} \\
\text { M (25\%; } 75 \%)\end{array}$ & $\begin{array}{c}\text { P } \\
\text { (MANN-WHITNEY U-TEST) }\end{array}$ & $\begin{array}{c}\text { DAY 60'H } \\
\text { M (25\%; } 75 \%)\end{array}$ & $\begin{array}{c}\text { P } \\
\text { (MANN-WHITNEY U-TEST) }\end{array}$ \\
\hline 1 & $\mathrm{EAE}, \mathrm{n}=7$ & $\begin{array}{c}0.43 \\
(0.34 ; 0.55)\end{array}$ & $P_{K-1}=0.003^{* * *}$ & $\begin{array}{c}0.47 \\
(0.39 ; 0.55)\end{array}$ & $\begin{array}{c}P_{1-3}=0.02^{*} \\
P_{K-1}<0.0001^{\star * \star}\end{array}$ \\
\hline 2 & EAE + UC-MMSCs cryo-1, $n=8$ & $\begin{array}{c}0.51 \\
(0.42 ; 0.58)\end{array}$ & $\begin{array}{c}P_{2-4}=0.012^{* *} \\
P_{K-2}<0.0001^{* \star *}\end{array}$ & $\begin{array}{c}0.51 \\
(0.42 ; 0.57)\end{array}$ & $\begin{array}{c}P_{2-3}=0.003^{* *} \\
P_{2-4}=0.011^{* *} \\
P_{K-2}<0.0001^{* * *}\end{array}$ \\
\hline 3 & EAE + UC-MMSCs cryo-2, $n=6$ & $\begin{array}{c}0.43 \\
(0.35 ; 0.47)\end{array}$ & - & $\begin{array}{c}0.37 \\
(0.32 ; 0.45)\end{array}$ & $\begin{array}{c}P_{1-3}=0.02^{\star} \\
P_{2-3}=0.001^{\star *}\end{array}$ \\
\hline 4 & EAE + UC-MMSCs cryo-3, $n=8$ & $\begin{array}{c}0.38 \\
(0.33 ; 0.43)\end{array}$ & $P_{2-4}=0.012^{* *}$ & $\begin{array}{c}0.39 \\
(0.30 ; 0.50)\end{array}$ & $P_{2-4}=0.011^{\star *}$ \\
\hline 5 & Control, $n=4$ & $\begin{array}{c}0.38 \\
(0.33 ; 0.43)\end{array}$ & $\begin{array}{l}\mathrm{P}_{\mathrm{K}-1}=0.003^{* * *} \\
\mathrm{P}_{\mathrm{K}-2}<0.0001^{* * *}\end{array}$ & $\begin{array}{c}0.33 \\
(0.29 ; 0.42)\end{array}$ & $\begin{array}{l}\mathrm{P}_{\mathrm{K}-1}<0.0001^{* \star *} \\
\mathrm{P}_{\mathrm{K}-2}<0.0001^{* \star *}\end{array}$ \\
\hline & $\begin{array}{l}\text { Notes: } M(25 \% ; 75 \%)(n), \text { where } M \text { is } \\
\text { * - significant compared group (EAE) a } \\
\text { ** - significant compared groups with } \\
\text { *** - significant compared control and }\end{array}$ & $\begin{array}{l}7 \text { with interquartile } \\
\text { with the injection } \\
\text { stration of UC-MM } \\
\text { tal groups. }\end{array}$ & $\begin{array}{l}\text { MSCs; } \\
\text { lopreserved according to di }\end{array}$ & rotocols; & \\
\hline
\end{tabular}

mellae order during severe diffuse interlamellar edema, as well as partial cleavage of the lamellae, in some cases with the acquisition of a typical shape (wavy, spiral, vesicular).

Thus, in rats with moderate EAE from the $35^{\text {th }}$ to the $60^{\text {th }}$ day after the induction of the disease, destructive changes and signs of demyelinating process in the spinal cord increase.

Group 2 (EAE + UC-MMSCs cryo-1). On the $35^{\text {th }}$ day of the experiment (the $17^{\text {th }}$ day after the injection of UC-MMSCs) the state of gray and white matter of the spinal cord was similar to group 1 (EAE): the number of altered neurons remained at the same level, the appearance of pre-apoptotic altered neurons was shown (Fig. 2 A). On the $60^{\text {th }}$ day (the $42^{\text {nd }}$ day after UC-MMSCs administration), a local increase in the size of mitochondria in the synaptic terminals of axo-dendritic synapses was detected, sometimes with a change in their shape, in particular, into annular (Fig. 2 B).
There was no decrease in the degree of demyelination compared with group 1. Interlaminar edema of myelin sheaths (Fig. 2 C), moderate periaxonal edema, disorganization of cytoskeleton and partial vacuolization of mitochondria of axis cylinders were detected. In the axis cylinders, an increase in the number of "young" newly formed mitochondria with a dense arrangement of cristae was noted (Fig. 2 D). At the same time, the MS/AC index increased statistically significantly by 1.5 times compared to the control on the $35^{\text {th }}$ day, remaining at the same level on the $60^{\text {th }}$ day $(p<0.0001)$ (table 3), which indicates the average degree of demyelination of axons with the transition to a high degree [24]. Obviously, the transplanted cryopreserved UC-MMSCs cryo-1 do not show a therapeutic effect on remyelination processes and are not able to stop the process of demyelination and growing of destructive changes in the spinal cord of rats with EAE.

Group 3 (EAE + UC-MMSCs cryo-2). On the $35^{\text {th }}$ day of the experiment (the $17^{\text {th }}$ day after the injection of UC-MMSCs), the structural changes of
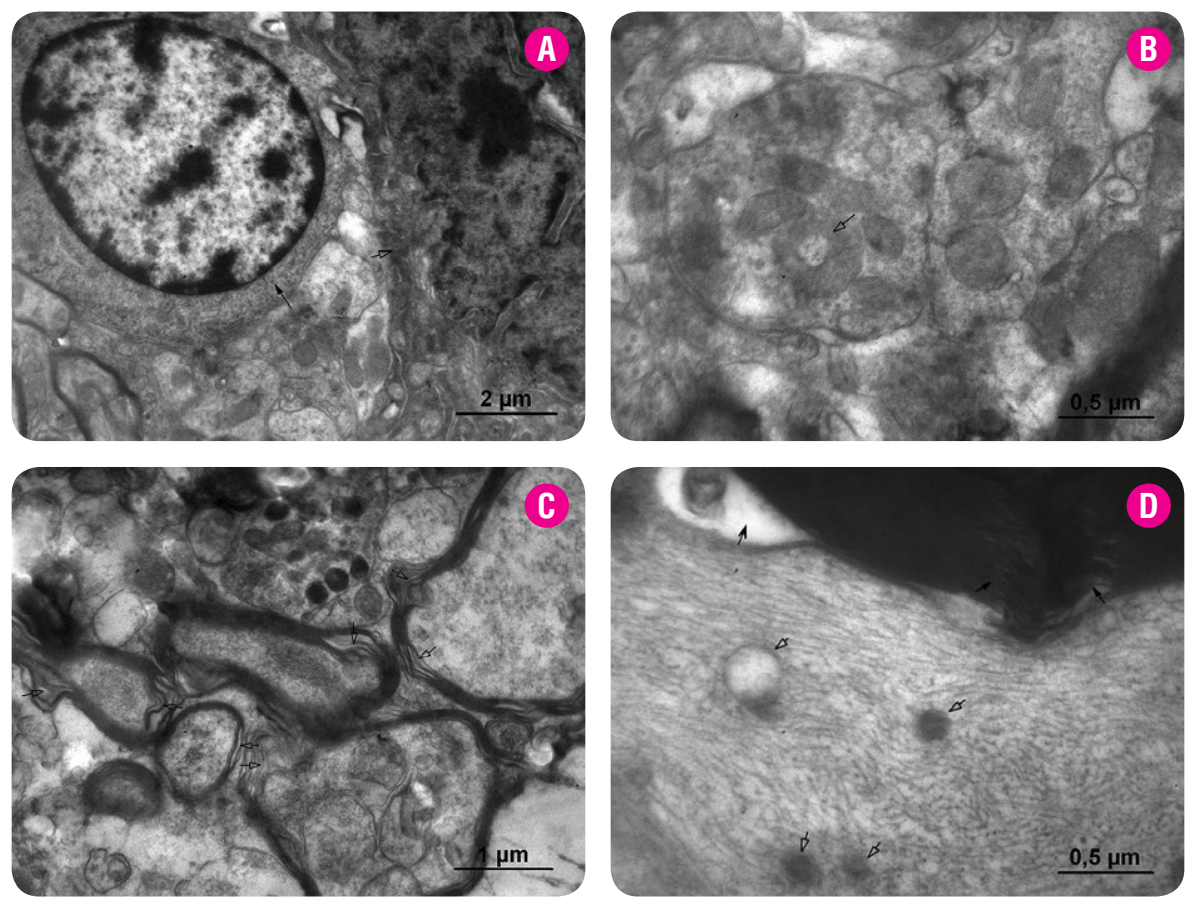

Fig. 2. Electronic microphotographs of rat spinal cord in group 2 (EAE + UC-MMSCs cryo-1):

A) oligodendrogliocytes of normal structure (dark arrow) and preapoptic altered neuron (hollow arrows), day 35;

B) modified annular mitochondria (hollow arrow) of the post-synaptic terminal of the axo-dendritic synapse, day 60;

C) interlamellar edema, stratification

of lamellae (hollow arrows) of myelin sheaths of axons, day 35;

D) periaxonal edema (arrows), local stratification of lamellae (arrows) of the myelin sheath of the axon, «young» newly formed and partially vacuolated types of intraaxonal mitochondria (hollow arrows), day 60 . 
the neurons were similar to those in groups 1 and 2 . In contrast to group 1 , there were significantly less swollen with low electron density synaptic terminals with a decrease in the number of synaptic vesicles. The ave-rage $M S / A C$ index did not differ from the value of group 1 (EAE). On the $60^{\text {th }}$ day (the $42^{\text {nd }}$ day after the adminstration of UC-MMSCs), the structural changes of neurons were polymorphic. Along with "dark" neurons, a significant number of "light" ones with reactive ultrastructural changes were detected (Fig. 3 A), which were almost indistinguishable in the structure of the nucleus and cytoplasm from unchanged neurons. The nucleus was characterized by a rounded shape, contained mainly euchromatin with light karyoplasm and one large nucleolus, located to the periphery of the nucleus. Perinuclear spaces sometimes had slight expansions. Slightly dilated EPR cisterns (Fig. 3 B), a Golgi complex of unchanged structure and a significant number of free ribosomes and polysomes, as well as lysosomes were observed in the cytoplasm. In contrast to the previous study period, on the $60^{\text {th }}$ day there was a decrease in the number of "dark" altered neurons relatively to the comparison group (EAE). The synaptic gap of most synapses was well contoured (Fig. $\mathbf{3} \mathbf{~ C}$ ) with a clear active zone. In synaptic contacts, synaptic vesicles were concentrated near the presynaptic membrane, the length of active zones increased, their osmophilia increased. The perforated contact zones were present, which is the morphological equivalent of increasing the structural and functional activity of the synapse [31].

At the same time, on the $60^{\text {th }}$ day, the stratification of myelin lamellae was observed not along the entire circumference of the axon, but in some limited areas of the myelin sheath that formed a protrusion. In myelinated axons, the state of axonal ultrastructure was normalized, the size of mitochondria increased (Fig. 3D) and numerous newly formed mitochondria with dense crystae were noted. The formation of internal loops of myelin, which is the ultrastructural equivalent of remyelination of nerve fibers [32], was detected. The MS/AC index of group 3 decreased statistically significantly by 1.3 times $(p=0.02)$ compared to the group $E A E$, and by 1.4 times $(p=0.011)$ compared to group 2 (table 3 ), acquiring values corresponding to a low degree of axonal demyelination [24].

Therefore, the transplanted cryopreserved UC-MMSCs cryo-2 have an effect on the altered spinal cord tissue of rats with EAE: the increase of destructive changes stops, the number of altered neurons decreases, there are signs of increased structural and functional activity of synapses, the degree of demyelination of axons of the white matter of the spinal cord decreases, the signs of remyelination (formation of internal loops of myelin) intensify, which provides grounds for the conclusion about the therapeutic effect of UC-MMSCs, cryopreserved in media type cryo-2.

Group 4 (EAE + UC-MMSCs cryo-3). In both study terms, the number of "dark" altered neurons in rats of group 4 did not decrease in comparison with the control group. A significant number of lysosomes as electron-dense granules of various sizes were observed in the perikaryons of neurons. This indicates the activation of the lysosomal system of neurons, and is probably partly related to the compensatory response to hypoxia due to EAE (Fig. 4 A). There was a partial normalization of the synaptic apparatus state (Fig. 4 B), increased structural and functional activity of synapses.

The defibering of the myelin sheaths remained significant, and the periaxonal edema slightly decreased. There was an increase in the number of intraaxonal organelles (microtubules, neurofilaments, mitochondria) (Fig. 4 C). The MS/AC index in group 4 decrease by 1.1 times on the $35^{\text {th }}$ day and 1.2 times on the $60^{\text {th }}$ day of observation compared to group 1 (EAE), acquiring values corresponding to a low degree of demyelination of axons [24], and they were statistically significantly different from the value of group $2\left(p=0.012\right.$ and $p=0.011$, respectively, on the $35^{\text {th }}$ and $60^{\text {th }}$ day of observation (table 3 ).

Thus, the transplanted cryopreserved UC-MMSCs cryo- 3 have a certain effect on the altered spinal cord tissue of rats with EAE: there is a partial normalization of the synaptic components, the degree of demyelination of axons of the spinal cord white matter reduces, which provides grounds for the conclusion about the presence of therapeutic effects of UC-MMSCs cryopreserved in media cryo-3.

The results of the study in the experimental groups of rats with $E A E$ and the administration of UC-MMSCs relatively to the comparison group (rats with EAE without cell transplantation) show a decrease in the degree of demyelination with a simultaneous partial decrease in intralamellar and almost complete decrease of periaxonal edema on the $60^{\text {th }}$ day of observation (the $42^{\text {nd }}$ day after cell transplantation) in groups of rats with $E A E$, followed by the transplantation of UC-MMSCs cryo-2 and UC-MMSCs cryo-3. At the same time, it should be noted that the remyelination took place in parallel with demyelination. The signs of nerve fiber remyelination in all experimental groups began to appear on the $35^{\text {th }}$ day of the study. The remyelination of nerve fibers was carried out by oligodendrogliocyte processes mainly due to the formation of internal loops of myelin (Fig. $4 \mathbf{D}$ ).

The obtained data on spontaneous remyelination in EAE correspond to the known data on the typical physiological regeneration of structural
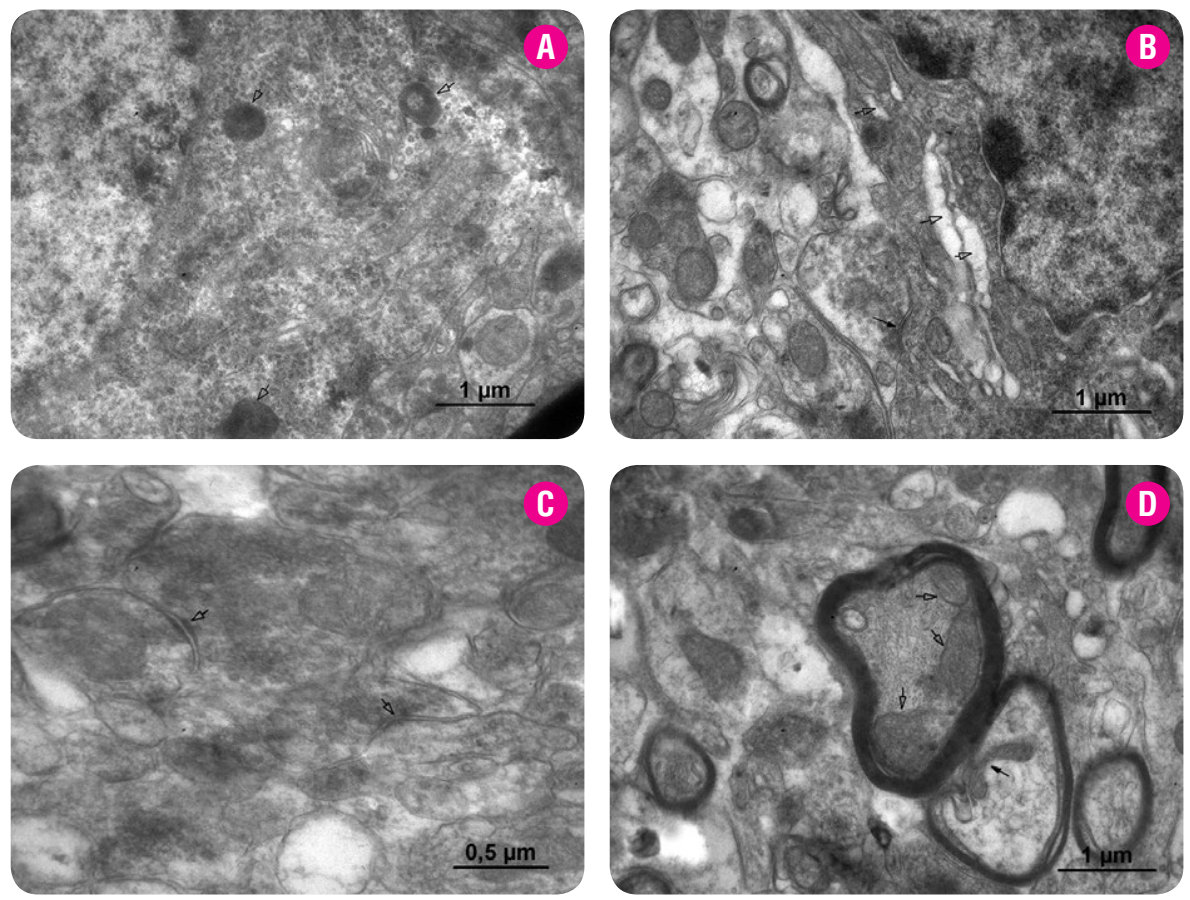

Fig. 3. Electronic microphotographs of rat spinal cord in group 3 (EAE + UC-MMSCs cryo-2):

A) the cytoplasm of the neuron contains

a large number of ribosomes and an increased number of small lysosomes (hollow arrows), day 35;

B) the expansion of EPR tubules (hollow arrows) in an altered neuron.

The normalization of the ultrastructure of the axo-somatic synapse (arrow points to the contact zone of the synapse), day 60 ; C) presynaptic terminals, with concave contact zones (hollow arrows), are full of synaptic vesicles, day 60 ;

D) increase in size (hollow arrows) and division of mitochondria by membrane (arrow) in myelinated axons of small diameter, day 60 . 
components in CNS at the molecular and cellular level, in particular, the constant restoration of myelin [33]. But, in multiple sclerosis and its model EAE, the demyelination of axons prevails over their remyelination, and endogenous processes in brain tissue are not complete. During myelination around the axons of neurons by oligodendrocytes, an intermittent membrane with a lamellar structure and a constant lipid-protein composition is formed. The precursors of oligodendrocytes (pre-progenitor, progenitor glial cells and pre-oligodendrocytes) are located in the white and gray matter of the brain of fetuses and adults of both people and rodents. The ability to proliferate and migrate is specific only for pre-progenitors and progenitor glial cells [33]. In addition to oligodendrocytes, neural stem cells are also included in the reparative process. In the foci with intensive remyelination, an increase in the number of cells with high reparative activity, specific of oligodendrocyte precursors, is registered. In the postnatal brain, oligodendrocyte progenitors migrate from the subventricular zone during myelin breakdown, which process supports inflammation [33].

The differences in the ultrastructure of the axis cylinders of the myelinated axons in the groups with the administration of UC-MMSCs largely appeared on the $60^{\text {th }}$ day of the experiment and were due to a decrease in the degree of swelling of myelinated axons and the normalization of intraaxonal mitochondria. It is believed that one of the causes of mitochondrial transformations is the presence of hypoxia/ischemia. Mitochondrial rearrangements are the structural equivalent of functional stress of cells under the influence of extreme factors and are considered as a neuroplastic reaction, indicating the inclusion of physiological compensatory mechanisms, which due to increased energy expenditure provide restoration of disturbed homeostasis [34, 35]. In our study, in animals with EAE and subsequent transplantation of UC-MMSCs, a part of the mitochondria of neurons and axons showed signs of ultrastructural regeneration (increase in the number and size of mitochondria), which is less typical of rats with EAE.

The revealed effects of cryopreserved UC-MMSCs cryo-2 and cryo-3 were, apparently, due to the preservation of the known UC-MMSCs of regenerative, anti-inflammatory and immunosuppressive directions under the specified conditions of cryopreservation [34, 35], which, apparently, affect the main pathogenetic links of the inflammatory and autoimmune process in $E A E$, and probably enhance endogenous regenerative processes in the CNS of rats with EAE. It is known that MMSCs are multipotent (capable of differentiation in adipo-, chondro- and osteogenic directions and transdifferentiation, including cells of the neural system), produce neurotrophic, neuroprotective, growth, anti-inflammatory and immunomodulatory mediators, which enhance the survival of neurons, neuro- and synaptogenesis [15, 38-41], inhibit the autoimmune reactions in $\operatorname{EAE}[5,6]$. In previous studies, we proved the positive effect of native UC-MMSCs, as well as genetically modified UC-MMSCs (transfected with a plasmid with the IL-10 gene) on the restoration of the myelin fibers of the spinal cord of rats with $\operatorname{EAE}[7,13]$. Previous studies have also shown immunosuppressive effects of native UC-MMSCs in rats with EAE: longterm suppression of cellular and humoral immune response (decreased proliferative function of T-lymphocytes (within 2 months of follow-up) and B-lymphocytes (during 1 month), myeloperoxidase activity of neutrophils (2 months) and the level of antibodies to the myelin basic protein (on the $63^{\text {rd }}$ day) $[11,12]$.

The analysis of the results of electron microscopic examination of the spinal cord of experimental groups of rats with EAE showed that the implementation of the therapeutic effect of cryopreserved UC-MMSCs depends on the composition of the cryopreservation media. The variants of cryoprotective media cryo-2 and cryo-3, in contrast to cryo-1, provide better preservation of regenerative and, apparently, immunosuppressive properties of these cells. It is morphologically confirmed by the reduce in the number of altered neurons, increase in the structural and functional activity of synapses, reduce in the degree of demyelination of axons of the spinal cord white matter and strengthening of the signs of remyelination, which is quantitatively objectified by MS/AC index. The therapeutic effect of UC-MMSCs cryo-2 was manifested on the $42^{\text {nd }}$ day after the injection of cells by a statistically significant decrease in the degree of demyelination of nerve fibers of the spinal cord. The therapeutic effect of UC-MMSCs cryo-3 was detected on the $17^{\text {th }}$ day after cell administration, persisting until the $42^{\text {nd }}$ day after administration, but the reduction in the degree of demyelination did not become statistically significant.

It is known that cryopreservation changes the characteristics of cells such as viability, adhesion, immunomodulation and metabolism [42]. According to our data, reducing the DMSO concentration in the cryopreservation solution from $10 \%$ to $4 \%$ and adding $6 \%$ trehalose (cryo-2 medium) provided better preservation of the therapeutic properties of UC-MMSCs to reduce the degree of demyelination in EAE. At the same time, the standard medium cryo-3 (10\% DMSO, $90 \%$ FBS) also ensured the preservation of these properties, but to a lesser extent than the cryo-2. The use of a multicomponent media cryo-1 containing $15 \%$ ethylene glycol, $3 \%$ DMSO, $10 \%$ sucrose, $12 \%$ trehalose and $60 \%$ FBS, did not achieve the goal of preserving the therapeutic properties of UC-MMSCs.
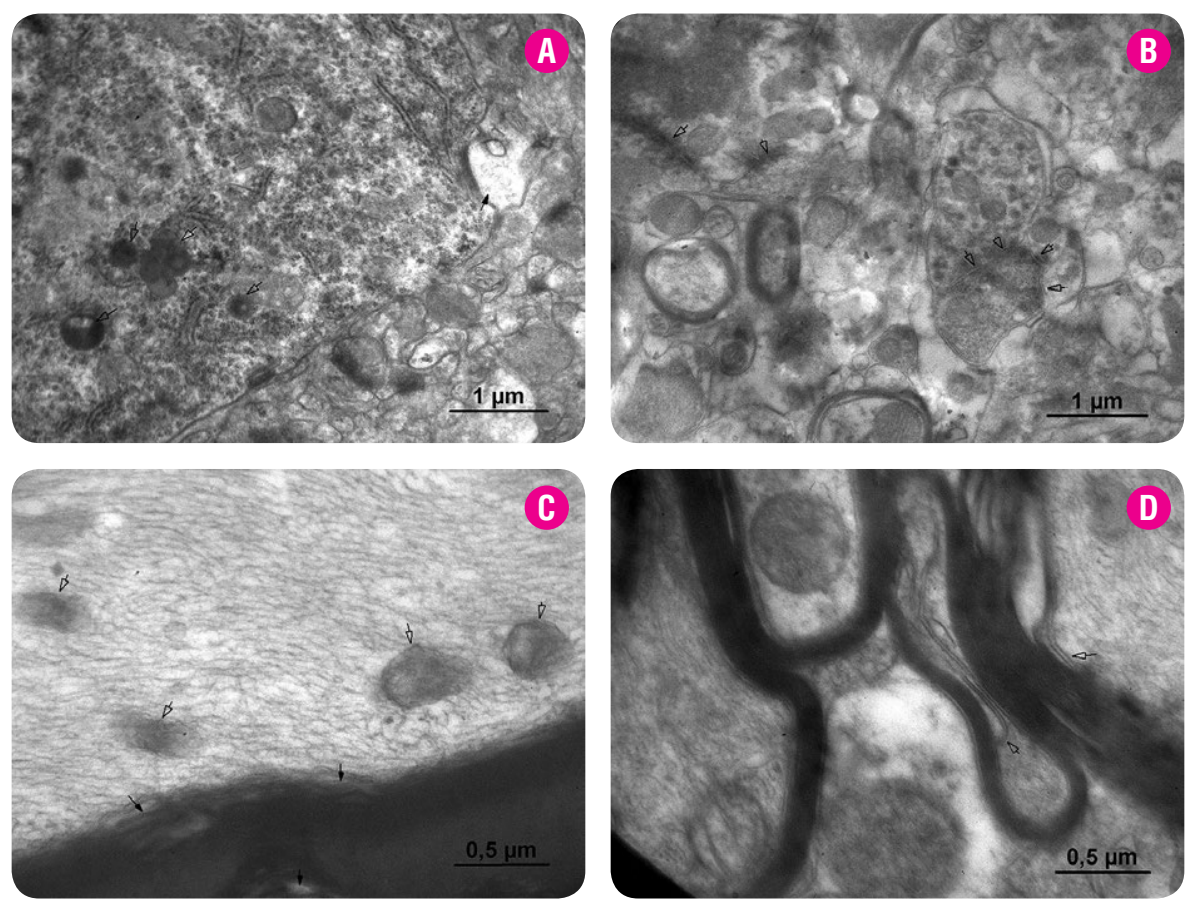

Fig. 4. Electronic microphotographs of rat spinal cord in group 4 (EAE + UC-MMSCs cryo-3):

A) the cytoplasm of the neuron contains a large number of lysosomes and lipofuscin granule (hollow arrows), lateral axo-somatic synapse with vacuolated presynaptic terminal (arrow), day 35;

B) synapses with perforated contact areas (hollow arrows), day 60;

C) focal defibering of myelin sheaths (arrow), numerous mitochondria in the axoplasm of myelinated axon (hollow arrows), day 60; D) internal loops of myelin (hollow arrows) of myelinated axon, formed by the processes of oligodendroglia, day 60 . 
The obtained data are fully consistent and are explained with the use of previously obtained data on the maximum preservation of the proliferative activity of UC-MMSCs after the cryopreservation in the cryoprotective media with the reduced concentration of DMSO from $10 \%$ to $4 \%$ with the addition of $6 \%$ trehalose (cryo-2), as well as high proliferative activity of cells after the cryopreservation in a standard medium (cryo-3), in contrast to the multicomponent (cryo-1), which is obviously associated with the changes in cell metabolism during cryopreservation in this medium [19].

As a result, it should be noted that in order to preserve the therapeutic properties of UC-MMSCs in the cryopreservation media, it is advisable to add a reduced concentration of DMSO $(4 \%)$ and $6 \%$ trehalose, supplemented with $90 \%$ FBS.

\section{CONCLUSION}

1. Suboccipitally administered UC-MMSCs cryopreserved in a medium containing of $15 \%$ ethylene glycol, $3 \%$ DMSO, $10 \%$ sucrose, $12 \%$ trehalose, $60 \%$ FBS, have no therapeutic effect on remyelination and are not able to stop the process of demyelination and increasing destructive changes in the spinal cord of rats with EAE.

2. Under the influence of suboccipital administration of UC-MMSCs, cryopreserved in a medium with $4 \%$ DMSO, $6 \%$ trehalose, $90 \%$ FBS, in rats with EAE, the demyelination is suspended on the $60^{\text {th }}$ day of observation, which morphological manifestations are a decrease in interlamellar and periaxonal swelling of myelinated axons, normalization of intraaxonal organelles, statistically significant reduction in the degree of demyelination.

3. Under the influence of suboccipital administration of UC-MMSCs, cryopreserved in a medium with $10 \%$ DMSO, $90 \%$ FBS, rats with EAE showed a tendency to reduce the degree of demyelination on the $17^{\text {th }}$ day after the administration of cells, which persists until the $42^{\text {nd }}$ day after transplantation.

4. Reducing the concentration of DMSO in the solution for cryopreservation from $10 \%$ to $4 \%$ and the addition of $6 \%$ trehalose provided better preservation of the therapeutic properties of UC-MMSCs to reduce the degree of demyelination in EAE.

Acknowledgments. The authors express their sincere gratitude to the Vitalii Kordium's laboratory of the Institute of Molecular Biology and Genetics of the National Academy of Sciences of Ukraine for the cryopreserved UC-MMSCs provided within collaborative study "To investigate the biological properties and determine the regenerative potential of cryopreserved human umbilical cord-derived mesenchymal stem cells in the experimental treatment of motor disorders» (project No. 0116U001030).

\section{REFERENCES:}

1. Pichkur LD, Verbovs'ka SA, Akinola ST, Chitaeva GE. The main pathogenetic mechanisms of the demyelination process in the central nervous system and the possibility of its correction. Ukr neurological journal. 2017; (2):12-19. [in Ukrainian].

2. Scuteri A, Donzelli E, Rigolio R, Ballarini E, Monfrini M, Crippa L, et al. Therapeutic Administration of Mesenchymal Stem Cells Abrogates the Relapse Phase in Chronic Relapsing-Remitting EAE. J Stem Cell Res Ther. 2015; 5:262. Available from: http://dx.doi.org/10.4172/2157-7633.1000262

3. Fong $C Y$, Chak LL, Biswas A, Tan JH, Gauthaman K, Chan WK, et al. Human Wharton's jelly stem cells have unique transcriptome profiles compared to human embryonic stem cells and other mesenchymal stem cells. Stem Cell Rev. 2011; 7:1-16. DOI: 10.1007/s12015-010-9166-X

4. Kovalchuk MV, Deryabina OG, Pichkur LD, Verbovskaya SA, Shuvalova NS, Pichkur OL, et al. Distribution of transplanted human mesenchymal stem cells from Wharton's Jelly in the central nervous systems of the EAE rats. Biopolym Cell. 2015; 31(5):371-378. DOI: 10.7124/bc.0008F9.

5. Zappia E, Casazza S, Pedemonte E, Benvenuto F, Bonanni I, Gerdoni E, et al. Mesenchymal stem cells ameliorate experimental autoimmune encephalomyelitis inducing T-cell anergy. Blood. 2005; 106(5):1755-1761. DOI: https://doi.org/10.1182/blood-2005-04-1496

6. Anderson P, Gonzalez-Rey E, O' Valle F, Martin F, J.Oliver F, Delgado M. Allogeneic Adipose-Derived Mesenchymal Stromal Cells Ameliorate Experimental Autoimmune Encephalomyelitis by Regulating Self-Reactive T Cell Responses and Dendritic Cell Function. Stem Cells International. 2017. Available from: https:// doi.org/10.1155/2017/2389753

7. Vaslovych VV, Pichkur LD, Malysheva TA, Akinola ST, Verbovs'ka SA, Toporova OK, et al. Ul'trastrukturni zminy spynnoho mozku shchuriv z eksperymental'nym alerhichnym entsefalomiyelitom pid vplyvom mezenkhimal'nykh stovburovykh klityn ta interleykina-10. Zhurnal klynycheskykh i eksperymental'nykh medytsynskykh issledovanyy. 2018; 1:17-30. [in Ukrainian].

8. Tsymbalyuk VI, Pichkur LD, Verbovs'ka SA, Akinola ST, Vaslovych VV, Deryabina $\mathrm{OH}$, et al. Vplyv ksenohennoyi transplantatsiyi natyvnykh i transfikovanykh henom interleykina 10 mezenkhimal'nykh stovburovykh klityn na perebih eksperymental'noho alerhichnoho entsefalomiyelitu. Visnyk problem biolohiyi i medytsyny. 2018; 2(1): 227-234. [in Ukrainian]

9. Tsymbaliuk VI, Velychko OM, Pichkur OL, Verbovska SA, Pichkur LD, Shuvalova NS. Effects of human Wharton's jelly-derived mesenchymal stem cells and interleukin-10 on behavioural responses of rats with experimental allergic encephalomyelitis. Cell Organ Transpl. 2015; 3(1):46-51. D0I: 10.22494/COT.V3I1.19

10. Kassis I, Petrou P. Halimi M, Karussis D. Mesenchymal Stem Cells (MSC) derived from mice with Experimental Autoimmune Encephalomyelitis (EAE) suppress EAE and have similar biological properties with MSC from healthy donors. Immunol Lett. 2013; 154(1-2):70-6. D0I: 10.1016/j.imlet.2013.06.002

11. Rudenko VA, Gnedkova IO, Pichkur DL, Verbovska SA, Pokholenko YaO. Influence of xenogenic transplantation of mesenchymal stem cells and II- 10 on cellular immunity in rats with experimental allergic encephalomyelitis. Collection of scientific works of staff members of NMAPE. 2014; 23(2):434-441. Available from: https:// https://nuozu.edu.ua/zagruzka/zbornikNMAP023_2.pdf. [in Ukrainian]

12. Rudenko VA, Belska LM, Verbovska SA, Pichkur OL. Neuroautoimmune reactions in rats with experimental allergic encephalomyelitis after treatment by xenogeneic MSCs and IL 10. Collection of scientific works of staff members of NMAPE. 2014; 23(3):447-452. https://nuozu.edu.ua/zagruzka/zbornikNMAP023_3.pdf. [in Ukrainian]

13. Akinola ST, Verbovs'ka SA, Vaslovych VV, Pichkur LD. Doslidzhennya vplyvu stovburovykh klityn na perebih eksperymental'noho alerhichnoho entsefalomiyelitu i morfofunktsional'nyy stan nervovykh volokon spynnoho mozku. Zb. nauk. prats' spivrobitnykiv NMAPO im. P. L. Shupika. 2017; 28:5-17. [in Ukrainian]. 
14. Skiles ML, Marzan AJ, Brown KS, Shamonki JM. Comparison of umbilical cord tissue-derived mesenchymal stromal cells isolated from cryopreserved material and extracted by explantation and digestion methods utilizing a split manufacturing model. Cytotherapy. 2020; 22(10):581-591. Available from: https://doi. org/10.1016/j.jcyt.2020.06.002

15. Maslova O, Novak M, Kruzliak P. Umbilical cord tissue-derived cells as therapeutic agents. Stem Cells International. 2015; 2015:1-10. D0I:10.1155/2015/150609

16. Best BP. Cryoprotectant toxicity: facts, issues, and questions. Rejuvenation Res. 2015; 18(5):422-36. D0I:10.1089/rej.2014.1656

17. Bersenev AV. Convulsions and coma as complications of DMSO-associated toxicity during infusion of hematopoietic cells in bone marrow transplantation. Cell Transplantology and Tissue Engineering. 2006; 1:31-32.

18. Mantri S, Kanungo S, Mohapatra P. Cryoprotective Effect of Disaccharides on Cord Blood Stem Cells with Minimal Use of DMSO. Indian Journal of Hematology and Blood Transfusion. 2014; 31(2):206-212. D0I:10.1007/s12288-014-0352-x

19. Tsymbaliuk V, Deryabina O, Shuvalova N, Verbovska S, Pichkur L, Oleksenko N, et al. Cryopreservation of human Wharton's jelly multipotent mesenchymal stromal cells with reduced concentration of dimethyl sulfoxide. Cell and Organ Transplantology. 2020; 8(1):51-57. D0l:10.22494/cot.v8i1.109

20. Pichkur LD, Semenova VM, Velychko OM, Verbovs'ka SA, Yehorova DM, Akinola ST, et al. Optymizatsiya modelyuvannya eksperymental'noho alerhichnoho entsefalomiyelita z khronichnym retsydyvuyuchym perebihom. Eksperymental'na i klinichna medytsyna. 2017; 4(77):4-14. [in Ukrainian]

21. Palade GE. A study of fixation for electron microscopy. J Exp Med. 1952; 95(3):285-298.

22. Gayer G. Electronic histochemistry. Moscow: Mir, 1974: 488 p. [in Russian]

23. Reynolds ES. The use of lead citrate at high pH as an electronopague stain in electron microscopy. J Cell Biol. 1963; 17:208-212.

24. Tsimbalyuk VI, Markova OV, Pichkur LD, Vaslovich VV, et al. A method of assessing the degree of demilinization of axons in experimental allergic encephalomies. Declarative patent for useful model No. 17499. Ukraine, IPC G 01N 23/02.- № 2006 05697; declared 05.24.06; publ. 09.15.06, Bul. No. 9. [in Ukrainian]

25. Rebrova OY. Statistical analysis of medical data. Application of the STATISTICA Application Package. Moscow: MediaSfera, 2002. 312 p. [in Russian]

26. Shabanov YES. Online synopsis of the course «Biometric data processing in zoology and ecology» 2011. Available from: https://batrachos.com/biometria. [in Russian]

27. Mastitsky SE, Shitikov VK. Statistical Analysis and Data Visualization with R. 2014. Available from: http: //r-analytics.blogspot.com. [in Russian]

28. Afanasyev Yul, Yurina NA, Kotovsky EF, et al. Histology, embryology, cytology: textbook, 6th ed. Moscow: GEOTAR-Media, 2012. 800 p. [in Russian]

29. Bogolepov NN. Brain ultrastructure during hypoxia. Moscow: Medicine, 1979: 168 p. [in Russian]

30. Li Q, Weiland A, Chen X, Lan X, Han X, Durham F, et al. Ultrastructural Characteristics of Neuronal Death and White Matter Injury in Mouse Brain Tissues After Intracerebral Hemorrhage: Coexistence of Ferroptosis, Autophagy, and Necrosis. Front Neurol. 2018; 9:581. D0I: 10.3389/fneur.2018.00581.

31. Frumkina LE, Yakovleva NI, Bogolepov NN. Mekhanizmy razvitiya sinapsa kak osnova ego involyutsii. Byulleten' eksperimental'noy biologii. $1993 ; 116: 214-217$. [in Russian]

32. Zavalishin IA, Golovkin VI. Multiple sclerosis. Selected questions of theory and practice. Moscow, 2000. 637 p. [in Russian]

33. Chekhonin VP, Davydovskaya MV, Lebedev SV, et al. Neurobiological bases of remyelination in the central nervous system. Annals of the Russian Academy of Medical Sciences. 2003; 8:43-52.

34. Zhivolupov SA, Samartsev IN, Syroezhkin FA. Sovremennaya kontseptsiya neyroplastichnosti (teoreticheskie aspekty i prakticheskaya znachimost'). Zhurnal nevrologii i psikhiatrii im. S. S. Korsakova. 2013; 10:102-108. [in Russian]

35. Meerlo P, Mistlberger RE, Jacobs BL, Heller HC, McGinty D. New neurons in the adult brain: the role of sleep and consequences of sleep loss. Sleep Med Rev. 2009; 13(3):187-194. DOI: 10.1016/j.smrv.2008.07.004

36. Gomzikova MO, James V, Rizvanov AA. Therapeutic Application of Mesenchymal Stem Cells Derived Extracellular Vesicles for Immunomodulation. Front Immunol. 2019; 10:1-9.

37. Zanier ER, Montinaro M, Vigano M, Villa $P$, Fumagalli $S$, Pischiutta $F$, et al. Human umbilical cord blood mesenchymal stem cells protect mice brain after trauma. Crit Care Med. 2011; 39:2501-2510.

38. Hsieh JY, Fu YS, Chang SJ, Tsuang YH, Wang HW. Functional module analysis reveals differential Osteogenic and stemness potentials in human mesenchymal stem cells from-bone marrow and Wharton's jelly of the umbilical cord. Stem Cells Dev. 2010; 19:1895-1910. Available from: https://doi.org/10.1089/scd.2009.0485. PMID:20367285

39. Konala VB, Mamidi MK, Bhonde R, Das AK, Pochampally R, Pal R. The current landscape of the mesenchymal stromal cell secretome. Cytotherapy. 2016; 18:1324. DOI:10.1016/j.jcyt.2015.10.008

40. Putra A, Ridwan BR, Putridewi Al, Kustiyah AR, Wirastuti K, Sadyah NA, et al. The role of TNF-alpha induced MSCs on suppressive inflammation by increasing TGF-beta and IL-10. Open Access Maced J Med Sci. 2018; 6(10):1779-1783.

41. Laroni A, Kerlego de Rosbo N, Uccelli A. Mesenchymal stem cells for the treatment of neurological diseases: immunoregulation beyond neuroprotection. Immunology letter. 2015; 168:183-190. Available from: http://dx.doi.org/10.1016/j.imlet.2015.08.007

42. Bahsoun S, Coopman K, Elizabeth C, Akam EC. The impact of cryopreservation on bone marrow derived mesenchymal stem cells: a systematic review. J Transl Med. 2019; 17:397. Available from: https://doi.org/10.1186/s12967-019-02136-7

\begin{tabular}{|l}
\hline \\
ARTICLE ON THE SITE \\
TRANSPLANTOLOGY.ORG
\end{tabular}




\title{
Ультраструктурні зміни спинного мозкущурів за впливу мультипотентних мезенхімальних стромальних клітин пуповини людини, кріоконсервованих за різними схемами, на тлі експериментального алергічного енцефаломієліту
}

\author{
Цимбалюк В. І. ${ }^{1}$, Васлович В. В. ${ }^{1}$, Пічкур Л. Д. ${ }^{1}$, Любич Л. Д. ${ }^{1}$, Малишева Т. А. ${ }^{1}$, Вербовська С. А. ${ }^{1}$, \\ Єгорова Д. М. ${ }^{1}$, Лонтковський Ю. А. ${ }^{2}$ \\ ${ }^{1}$ Державна установа «Інститут нейрохірургії ім. акад. А. П. Ромоданова Національної академії медичних наук \\ України», Київ, Україна \\ ${ }^{2}$ Медичний центр «МЕДЛОН», м. Кам'янеиь-Подільський, Украӥна
}

\section{РЕЗЮME}

Трансплантацію мультипотентних мезенхімальних стромальних клітин (ММСК) розглядають як можливий напрям патогенетичної терапії розсіяного склерозу. 3 метою клінічного застосування ММСК пуповини (ММСК-П) людини необхідно розробити методику їх кріоконсервування з урахуванням виду кріоконсерванту та дослідити можливість застосування цих клітин з терапевтичною метою in vivo.

МЕТА РОБОТИ - дослідження впливу ММСК-П, кріоконсервованих у консервантах різного складу, на процеси де- і ремієлінізації спинного мозку щурів із експериментальним алергічним енцесраломієлітом (ЕАE), як моделлю розсіяного склерозу.

МАТЕРІАЛИ ТА МЕТОДИ. Щурам з моделЛю ЕАЕ середнього ступеня тяжкості з хронічним ремітуючим перебігом, відтворену підшкірним введенням гомогенізованого спинного мозку дорослих щурів з повним ад'ювантом Фрейнда, на 18-у добу експерименту субокципітально вводили 1.106 ММСК-П, попередньо кріоконсервованих в кріопротекторних розчинах, що містили в різних комбінаціях диметилсульфоксид (ДМСО), фретальну телячу сироватку (ФТС), етиленгліколь, трегалозу та сахарозу. На 35-у і 60-у добу проводили дослідження ультраструктурних змін поперекових відділів (L3-L5) спинного мозку, оцінюючи ступінь демієлінізації нервових волокон за коефіцієнтом відношення товщини мієлінової оболонки (МО) до діаметра осьового циліндра (ОЦ) аксонів.

РЕЗУЛЬТАТИ. У щурів з відтвореним ЕАЕ середнього ступеня тяжкості з 35-ї по 60-у добу після індукції захворювання у спинному мозку нарощувались деструктивні зміни та ознаки демієлінізуючого процесу; показник МО/ОЦ відповідав середньому ступеню демієлінізації аксонів. Введені субокципітально щурам з ЕАЕ кріоконсервовані ММСК-П, залежно від застосованого розчину для кріоконсервування, сповільнювали чи зупиняли процес демієлінізації, знижуючи МО/ОЦ до показника, що відповідає низькому ступеню демієлінізації аксонів. Зменшення концентрації ДМСО у розчині для кріоконсервації $310 \%$ до 4 \% та додавання 6 \% трегалози забезпечувало краще збереження ефрективності ММСК-П щодо зниження ступеня демієлінізації при ЕАЕ. Водночас, стандартне кріопротекторне середовище (10\% ДМСО, 90 \% ФТС) забезпечувало збереження вказаних властивостей, але меншою мірою. Застосування багатокомпонентного розчину із вмістом 15 \% етиленгліколю, З \% ДМСО, 10 \% сахарози, 12 \% трегалози та 60 \% ФТС не досягло мети збереження нейропротекторних властивостей ММСК-П щодо зниження ступеня демієлінізації при $E A E$.

Висновки: Для збереження нейропротекторних терапевтичних властивостей ММСК-П у розчин для кріоконсервування доцільно додавати зменшену концентрацію ДМСО (4 \%) та 6 \% трегалози, залишаючи 90 \% фетальної телячої сироватки.

ключові СловА: демієлінізація; ремієлінізація; мультипотентні мезенхімальні стромальні клітини; кріоконсервування клітин 